確率型ファジィ推論の一提案とその磁気ヘッド調整への適用

$\begin{array}{rlllll}\text { 正員 } & \text { 石丸 伊知郎 } & \text { (日立) } & \text { 非会員 } & \text { 平林 久明 } & \text { (日立) } \\ \text { 非会貝 } & \text { 森里 美奈子 } & \text { (日立) } & \text { 正員 } & \text { 浅野 敏郎 } & \text { (日立) } \\ \text { 非会員 } & \text { 北川 泰治 } & \text { (日立) } & & & \end{array}$

\title{
A Proposal of Probability Type Fuzzy Inference and its Application to Magnetic Head Adjustment
}

Ichirou Ishimaru, Member, Hisaaki Hirabayashi, Non-member, Minako Mor isato, Non-member, Toshio Asano, Member, Taiji Kitagawa, Non-member (Hitachi Ltd.)

\begin{abstract}
Proficiency in creating a konwledge base is required for high accuracy fuzzy control. To achieve this we propose a new fuzzy inference method utilizing probability density functions of distiributions of mesurement values defined as membership functions. In addition, to consider qualitative knowledge of the data distribution, we propose a method to determine the membership functions using the distributions of grade accumulation. We applied the proposed method to automatic high accuracy adjustment devices for magnetic head, and the experimental results were satisfactory.
\end{abstract}

キーワード：確率密度関数, ファジィ推論, メンバーシップ関数, 累積, 磁気ヘッド, 調整, 高精度

\section{1。まえがき}

近年，高度な技術を要する作業への従事者不足のため， 熟練官能作業と呼ばれる技能の伝承が非常に困難となって きている。熟練作業者は多くの事柄（多入力）を鑑みなが ら，その非線形性，あるいは相互の干涉等を巧みに考慮し， 複数の操作量（多出力）を決定している。また，溶鉱炉内 の温度分布等, 制御に必要な情報の測定すらも困難な場合 もあり，従来のフィードバックを前提とした線形制御技術 では分な対応を行うことはできなった。熟練作業者の 知識をコンピュー夕に処理させ，その作業を支援あるいは 自動制御を行う手法として,ファジィ, ニューロの技術が 有效であることが知られている1)〜5》。これは，雨技術の 持つ非線形関数近似能力の高さ, 及び, 多入力多出力を扱 うことが容易であると言う特徴に負うところが大さい。し かし，ファジィ制御を れる高精度な制御に用いる場合は，メンバーシップ関数の 設計方法が非常に重要となる。

メンバーシップ関数の定義方法に, ニューロの学習則で ある最急降下法を適用する手法が提案されている6) 9 。 この場合，教示デー夕には一意性（同じ入力值に対して異 なる出力值を認めない) が求められるが, 実際観測される データは様々なばらつきを持っている。しかし, ファジィ, ニューロ共に教示データのばらつきの扱い方に関して取り 組んだ研究は無かった。

また,ファジィを確率の一種として捉えることも可能で あろうという見解は述べら机ているが10), 具体的な手法に
ついては事例が無い。

本論文ではデー夕のばらつき具合をつアジネスとして捉 え，そのばらつきの確率密度関数に基づいてメンバーシッ プ関数定義し，このメンバーシップ関数を用いた確率型 ファジィ推論を提案する。本論文ではさらにばらつきの 原因に付いての定性的な知見をも考慮してメンバーシッフ 関数を定義し（累積グレードメンバーシップ関数），より 高精度な推論精度を得る手法を提案する。

以下，本諭文の2，3章ではデータのばらつきを考慮す るに至ったニーズとして具体的に磁気へッド調整の概要と 調整アルゴリズムの課題を述ベる。そして，4 章で確率型 ファジイ推諭と累積グレードメンバーシッブ関数による推 墖法を提案し，5章で磁気へッド調整に本手法を適用した 実験結果を示す。6章はむすびである。

\section{2、磁気ヘッドの構成，及び，調整概要}

図 1 に磁気ヘッドの構成を示す。磁気へッドは真鍮製の ヘッドベースと,アモルファス製, あるいは, フェライト 製のヘッドチップより構成されている。ヘッドベースは先 端が 2 つに分か机ており，その2 箇所の突起部それぞれに ヘッドチップを接着により固定した構造となっている。こ れら2枚のヘッドチップには，読み書きを行うための ギャップと呼ばれるスりットがそれそれ形成されており， 图 2 に示すようにこの横方向の距離をギャップ間距離, あ る基準面からのそれぞれの高さを絶対高さ，また，その差 である相対高さをハイト段差と称する。

近年磁気記録の高密度化に伴い, 上記寸法の所定寸法か 


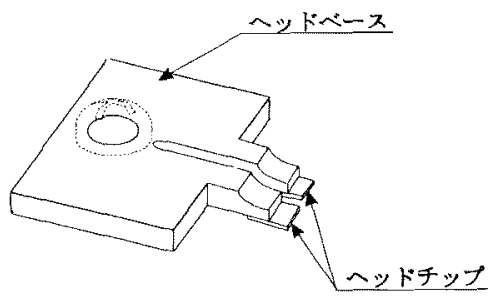

図 1 磁気へッド構成図

Fig.1. Structure of magnetic head.

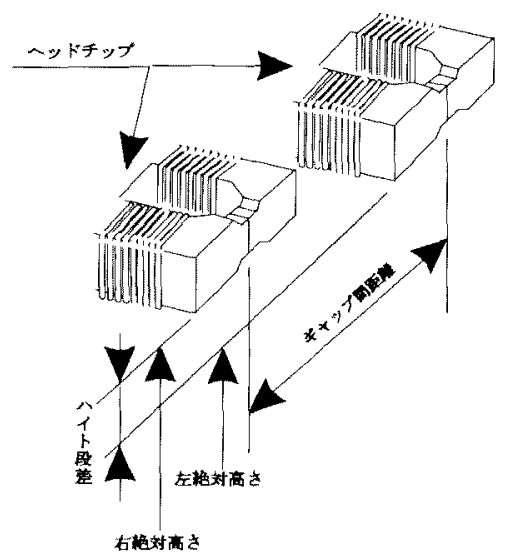

図 2 調整項目

Fig.2. Adjustment item.

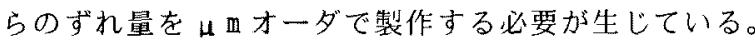
ヘッドチップをへッドベースに接着固定する際にも数十山吅 オーダで寸法管理を行っているが，それだけでは不十分で あり，その後再調整を行う必要がある。従来は，作業者が 顕微鏡を用いて目視により上記各寸法を测定し，小型の万 力を改良した治具を用いてへッドベースを高精度に塑性変 形させ調整を行っていた。しかし，多量の磁気へッドを人 手により調整することは非能率であるばかりでなく，高精 度の調整が作業者に与えるストレスが大きく，自動化の要 求が高まっている。

図 3 に自動機の調整機構概要を示す。本論文は調整アル ゴリズムに関するものであるため，機棈あるいは各種寸法 の測定装置に関する詳細は既報を参照されたい!!。図3

(a)はギヤップ間距離広げ調整機構である。これはくさ びをへッドベース先端の割れ目に押し込み，その縦方向の 押し込み量を制御することにより広げ量を制御している。 図3（b）は八イト調整機構である。これは，2 本の棒状 のッールにより右，左それぞれの突起部を押し上げて調整 を行う。絶対高さが低目になるようにへッドチップを接着 固定し，押し上げのみで調整可能としている。図 3 (c) はギャップ間距離狭め調整機構である。これは乫起部を雨 側から挟みこむことによりギャップ間隔を狭める。

制御可能なのはこれらの機構の移動量（以下，総合変形 量と称する)である。しかし，弾性変形分であるスプりン グバック量は戻ってしまうため，調整量である塑性変形量

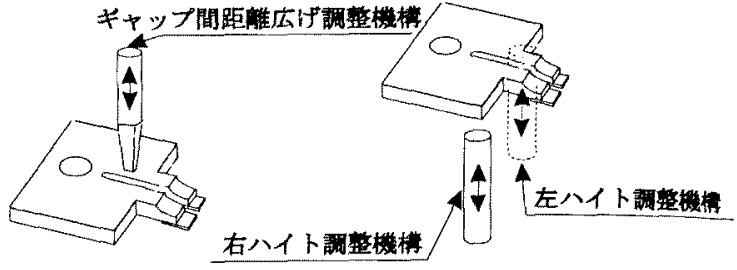

(a)

(b)

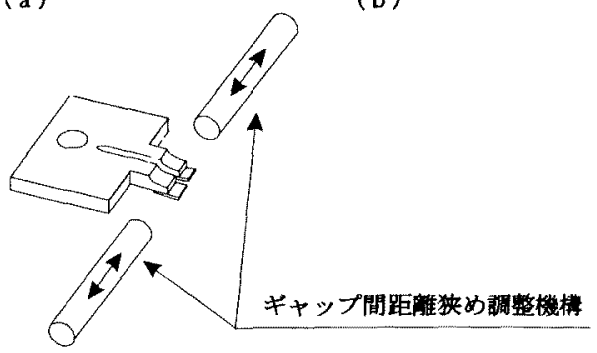

(c)

図 3 調整機構概要

Fig.3. Mechanical configuration for adjustment.

よりスプリングバック量を見込んだ総合変形量を求めなく てはならない。

3. 調整アルゴリズムの課題

調整アルゴリズムが解決しなければならない課題は以下 の 4 点であった。

（1）総合変形量を同量だけ与えても，スプリング バック量にはばらつきがある。

（2）総合変形量と塑性変形量の関係は非線形である。

（3）八イト方向とギャップ間隔方向に相互千涉があ る。

（4）調整履歴の影響がある。

以下，上記課題について詳細に説明を行う。

<3，1> 塑性変形量のばらつきと非線形性 図 4

(a)に右八イト調整機構を用いてへッドをある総合変形 量で変形させた場合の，ハイト段差塑性変形量の度数分布 を示す。図中の黒い棒で示すヒストグラムは総合変形量を $110 \mu \mathrm{m}$ とした時に得られた塑性変形量である。サンプル 数は 59 個であった。このように，同じ総合変形量で変形 を行っても異なる塑性変形量を生じてしまう。このばらつ きの原因は様々考えられるが，1つの要因としてはヘッド ベースの板厚のばらつきが考えられる。最終的な製品の性 能に板厚は関係ないため，板厚の寸法精度は粗い。そのた め, デー夕のばらつきの中に板厚が厚いものは曲がり難く， 板厚が薄いものは曲がり易いと言う定性的な傾向を見るこ とはできる（第 4 章第 3 節において詳述する。図 10 参 照）。

図4（b）位数分布の平均值をとった時のハイト段差 塑性変形量と総合変形量との関係を示す。この非線形性を も考慮する必要がある。 


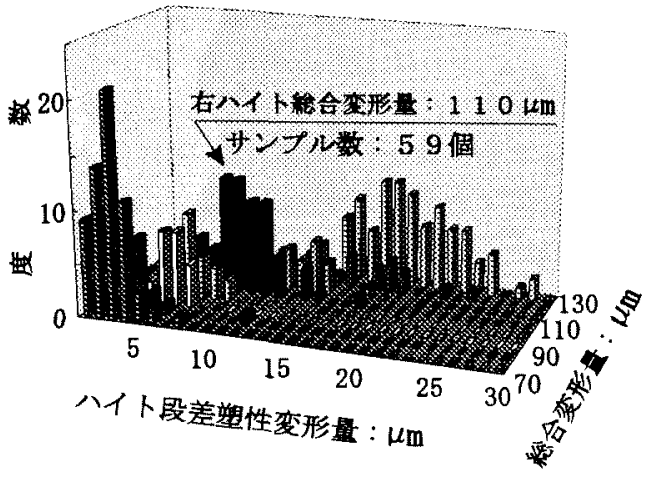

（a）塑性変形量のばらつき (度数分布)

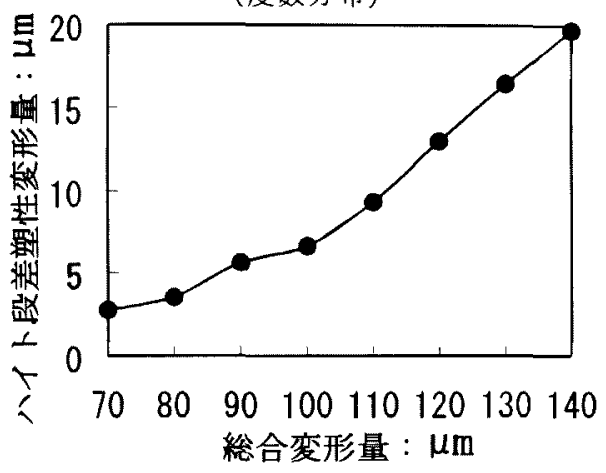

（b）塑性変形量の非線形性

図 4 塑性変形量のばらつきと非線形性

Fig.4. Distribution and nonlinearity of plastic deformation.

<3.2> 相互干渉 ギャップ間距離広げ調整機構 による幅方向の調整では，くさびを打ち込むため図 5

(a)に示すようにへッドベース突き出し部は幅方向だけ でなく下方向にも引きずられ，高さ方向まで塑性変形して しまう。また，ハイト調整機構により高さ方向の調整を行 うと，突き出し部の付け根を回転中心として変形するため， 図 5 (b) に示すように幅方向が狭まる。このように ギャップ閒隔方向と高さ方向を独立して調整することがで きないため，それぞれの相互干涉量を加味して調整量を決 定する必要がある。

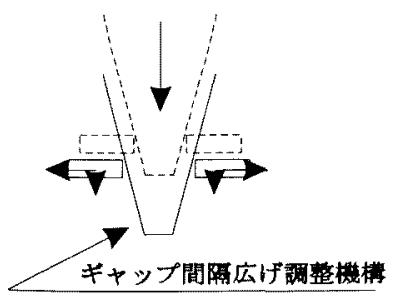

(a)

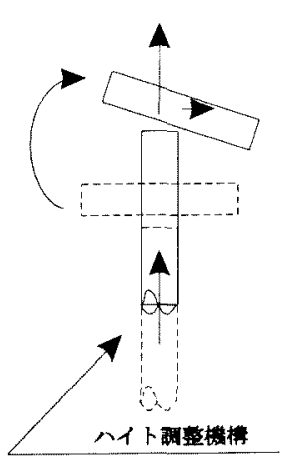

(b)
図 5 相互干涉

Fig.5. Mutual interference.
$<3.3>$ 調整履歴の影響塑性変形には加工硬化， バウジンガ効果と呼ばれる現象があり，既に塑性変形させ たものは，その塑性変形をした方向, 及び, 量（調整履 歴）を考慮しなけ扎ば的確な総合変形量を求めることがで きない。有限要素法を用いてへッドベースの応力解析を 行った。その結果ギャップ間隔方向, 高さ方向調整伴に, 同じへッドバース突き出し部付け根部分を塑性させること が判明した。このため, 高さ方向の調整量を決定する場合 は以前のギャッブ間隔の調整方向, 及び, 量を, またその 逆の場合も同様に調整履歴を考慮しなけ扎ばならないこと が予想された。

4. 累積適合度メンバーシップ関数による確率型 ファジィ調整アルゴリズム

$<4.1>$ 確率型ファジィ推論の基本概念（塑性変形 量のばらつきの考虑） まず最も判り易い1入力 1 出力 の場合を用いて説明する。右ハイト調整機構のみにより， 相互干涉を無視してハイト段差のみを調整するための総合 変形量を算出する場合を例に説明する。

ここで求めたいのは目標とする八イト段差塑性変形量を 与える総合変形量であるが, 図 4（a）に示したように， 同じ総合変形量に対しても, 得られる塑性変形量はばらつ いてしまう。図 4（a）から縦軸が確率を表す図6のよう な確率曲面を考える。この曲面において塑性変形量 $a$ を得 たい場合の総合変形量のばらつきは図 7 に示す $\mathrm{a}$ - $\mathrm{a}$ ’断 面で表すことができる。この内 1 番尤もらしいところを解 として求めればよく，この場合は $\mathrm{a}-\mathrm{a}$ ’断面の重心が一 番尤もらしいので, この值をハイト段差調整の操作量とす る。

以上の操作量を求める演算を, ファジィ推論法として定 式化する。まず，総合変形量に対する塑性変形量の分布を

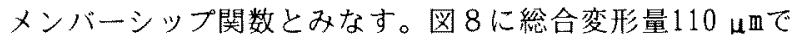
右ハイトを変形した時のハイト段差塑性変形量のばらつき を示す確率の分布を示す。平均 $\alpha$, 標準偏差 $\sigma$ の連続確率 変数 $x$ についての正規分布の確率密度関数 $f(x)$ は,

$$
f(x)=\frac{1}{\sigma \sqrt{2 \pi}} \exp \left(-\frac{1}{2}\left(\frac{x-\alpha}{\sigma}\right)^{2}\right) \ldots . .
$$

であり，その確率分布関数 $F(x)$ は，

$$
F(x)=\frac{1}{\sigma \sqrt{2 \pi}} \int_{-\infty}^{x} \exp \left(-\frac{1}{2}\left(\frac{v-\alpha}{\sigma}\right)^{2}\right) d v \ldots .
$$

である。そのため, 連続確率変数 $x$ が区間 $[a, b]$ にる確率 $p(a \leq x \leq b)$ は，

$$
p(a \leq x \leq b)=F(b)-F(a) \cdots \cdots \cdot \cdots
$$

により求めることができる。（1）式の積分は初等的方法 で評価はされないが(2)13，連続確率変数がxのまわりの幅 hの小区間に入る確率は大体

$$
f(x) \cdot h
$$

である14!。そこで

$$
p(x)=f(x) \cdot h=\frac{h}{\sigma \sqrt{2 \pi}} \exp \left(-\frac{1}{2}\left(\frac{x-\alpha}{\sigma}\right)^{2}\right) .
$$


として確率を求めた。本事例においては小区間幅 $h$ を ギャップ澌定の分解能である1 1 mとした。

図8の左側の縦軸は度数分布の度数を，右側の縦軸は

（5）式により求めた確率を示している。これより，塑性 変形量のばらつきを正規分布で近似することとする。この 近似の妥当性は最終的な調整結果の良否で判定する。そし て，メンバーシップ関数をこの（5）式を用いて定義する。 確率は 1 を越えることは無いため, 本メンバーシップ関数 のグレードの最大值は 1 より小さくなる。この場合, 確率 密度関数の定義上どのような入力值に対しても確率，つま りグレードが0となることはありえない。つまり，メン バーシップ関数の台集合は無限であることとなる。しかし， 台集合が有限でなければならない制約はメンバーシップ関 数の定義上なく，メンバーシップ関数の条件を満たしてい る。8通りの総合変形量に対する塑性変形量の分布加ら 8 種類のメンバーシップ関数を定義した。また，後件部操作 量は一意に与えた量であるため,ファジィルールとしては 後件部がシングルトンである, 次のようなIF-THENルール を得ることができる。

もしハイト段差を約9.3山塑性変形させたい

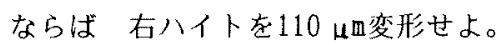

ファジイ推墖に抒いては，以上のメンバーシップ関数と， I FーT H E Nルールを用いて推論を行う。

1 入力 1 出力のファジィ推論は, 八イト段差を $\mathrm{x}$, 総合 変形量をyとすれば，

$$
\begin{array}{r}
R: \text { If } x \text { is } A \text {, then } y=f_{i} \\
\quad(i=1,2, \cdots, 8) \\
\begin{array}{r}
\mu_{i}=A_{i}(x) \\
y^{*}=\sum_{i} \mu_{i} \cdot f_{i}
\end{array}
\end{array}
$$

となる。ここで, Riはi番目のファジィルール， $\mathrm{A}_{\mathrm{i}}$ は ファジィ変数, $\mathrm{f}_{\mathrm{i}}$ 仗定数， $\mu_{\mathrm{i}}$ は $\mathrm{R}$ の前件部適合度, $\mathrm{y}^{*}$ は推諭值である。

図 9 に推論過程の例を示す。例えば，ハイト段差を5 山哇性変形させたいとする。まずそれそれれルールの適 合度を前件部において求め，これを後件部のメンバーシッ プのグレードとする。そして, 図 9 中右下に示すように 各々のルールで求まった総合変形量の重心をもって推論結

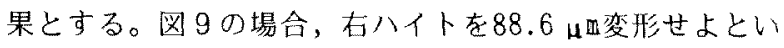
う推論結果が得られる。

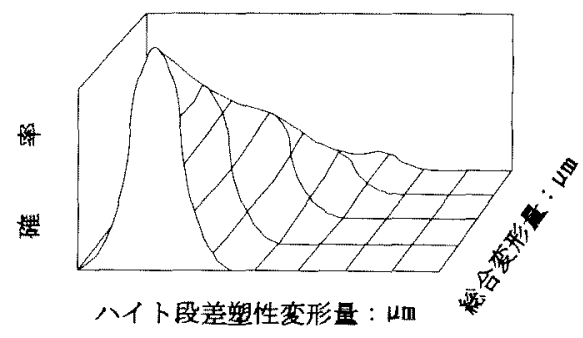

図 6 確率曲面

Fig.6. Curved surface of probability.

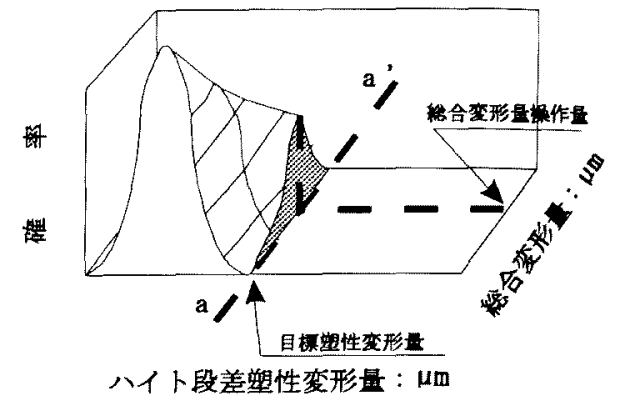

図 7 確率曲面断面

Fig.7. Sectional plain of probability curved surface.

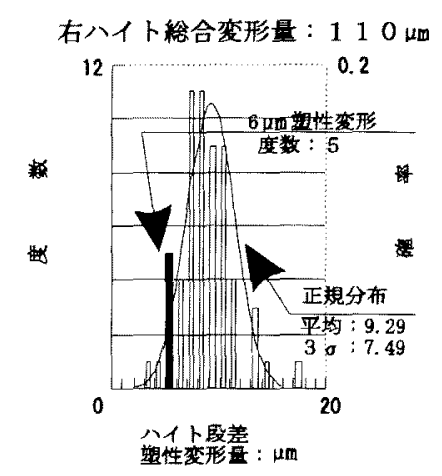

図 8 塑性変形量ばらつき

Fig.8. Distribution of plastic deformation.

<4.2> 多入力多出力時の確率型ファジィ推論（相 互干涉, 調整履歴の考慮) 1 入力 1 出力の推論では, 形式はファジィ推論であっても，実質的には図6の確率曲 面の棱線もしくは図 4 (b) の関係を入出力関係としてい ることとほほ等価である。本論文で扱っている磁気ヘッド 調整のような問題では相互干涉や調整履歴の影響があるの で得られるファジィルールは多入力多出力となる。ファ ジィ推論はこのような時にこそ効果を発揮する。

絶対高さの調整実験からは，例えば以下のような知見を 得ることができる。

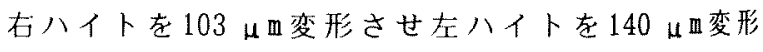
させると

右ハイトは約 $5 \mu$ 四塑性変形する。

左ハイトは約 $15 \mu \mathrm{m}$ 塑性変形する。

しかし，ギャップ間距離も約 3 几塑性変形してしまう。 このように，左右ハイトのみ変形させてもギャップ間距離 も塑性变形してしまう。相互干涉による塑性変形は报い難 いものとして認識されがちであるが，この知見を逆に見れ ば,

もし 右ハイトを約 $5 \mu \mathrm{m}$ 塑性変形させ

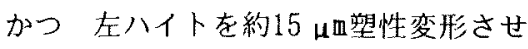

かつギャップ間距離も約 $3 \mu \mathrm{m}$ 塑性変形させたい

ならば右ハイトを103 $\mu \mathrm{m}$ 変形させ 
かつ 左ハイトを140 $\mu \mathrm{m}$ 変形させ

かつギャップ幅は調整しなくてもよい。

というファジィルールを得ることができる。この場合 3 入 力3出力の非線形モデリングが必要となるが，本論文の確 率型ファジィ推論によれば多入力多出力の非線形モデリン グにも容易に対応できるため，相互干涉を簡単に考慮でき る。

3 入力 $\mathrm{x}_{1}, \mathrm{x}_{2}, \mathrm{x}_{3}$, 出力 $\mathrm{y}$ の時, ファジィ推論は,

$R^{i}$ : If $x_{1}$ is $A_{i 1}$ and

$x_{2}$ is $A_{i 2}$ and

$\mathrm{X}_{3}$ is $\mathrm{A}_{\text {i3 }}$

then $y=f$

$\left(i=1,2, \cdots, n_{R}\right) \quad \cdots \cdot$

$\mu_{i}=A_{i 1}\left(x_{1}\right) \cdot A_{12}\left(x_{1}\right) \cdot A_{i 3}\left(x_{j}\right)$

$$
y^{*}=\sum_{i} \mu_{i} \cdot f_{i} / \sum_{i} \mu_{i}
$$

となる。ここで， $\mathrm{n}_{\S}$ はルール数。

本論文の確率型ファジィ推論では，3 入力の場合の前件

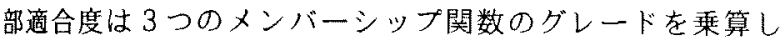
て求めた。本推墖法は, 前件部の3 条件を共に霂たす確率 を求め, その確率に応じて推論值を決定することを実現し ている。

調整履歴の考慮も相互干涉の考虑と同様に考元る。右八 イト調整を行った後の左ハイト調整のルールの一例を示す。

छL

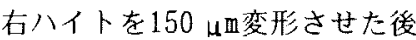

かつハイト段差を一 $-3.5 \mu$ 田塑性変形させる

ならば左ハイトを150 $\mu$ 四変形せよ。

$<4.3>$ 定性的知見の考慮（累積適合度メンバー シップ関数）以上述べた手法においてはばらつきその ものを小さくすることはできない。つまり，図8の例の場

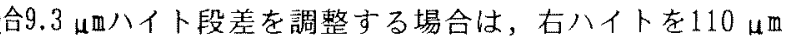
て変形させることとなるが, 実験結果より $3 \sigma て ゙$ 約 $7 \mu \mathrm{m}$ のばらつきを持っているため, 調整 1 回でこ机以上の精度 で調整を行うことはできない。しかし，ばらつきの要因が かかればより精度良く調整を行うことが可能となる。

$<3 ． 1>$ 節の図 4（a）を例に説明する。右ハイトを 慈合変形量 $110 \mu \mathrm{m}$ で変形させた場合，八イト段差塑性変形 量のばらつきは $3 \sigma=7.49 \mu$ 四であった。このサンプル (試験ヘッド) 数は59個あり，それぞれのへッドバースの 板厚は静電容量センサにより測定を行っている。

図10に板厚のばらつきと塑性変形量のばらつきとの関 係を示す。図中のけ印が実測値であり, 実線は最小自乗法 により得た。この相関係数の絶対值は 0.31 と小さいが概略 板㫗の厚目のものは塑性変形量が小さく, 薄めのものは塑 性変形量が大きいことが判る。そこで，この分布を板厚の 情報に基づいてファジィ分割する。図 11 にヘッドベース 股厚のメンバーシップ関数を示す。ファジィ分割は例えば， 望性変形量 $6 \mu \mathrm{m}$ (サンプル数： 5 個）の1つのサンプル つ板厚が0.96m⿴囗十あれば，薄いというメンバーシップ関数 カグレードは0.51，普通，厚いにはそれそれれ0.49，0.0と

電学論C, 117 巻 4 号, 平成 9 年

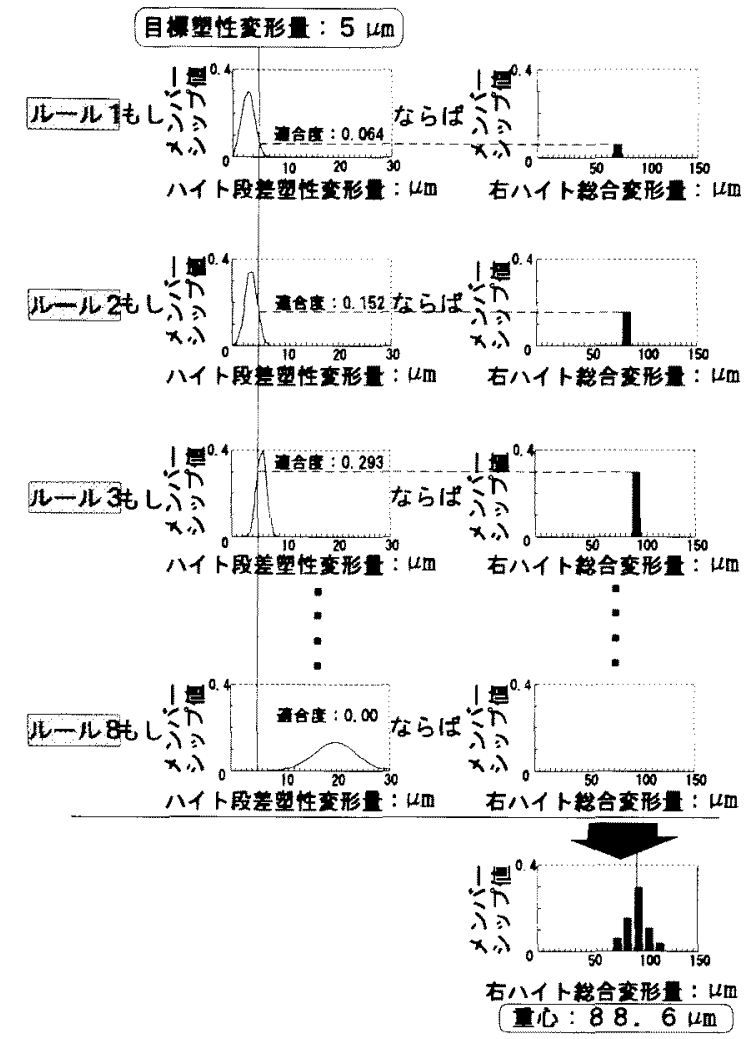

図 9 ファジィ推論過程（1 入力1 出力）

Fig. 9. Process of fuzzy inference (1 input, 1 output).

なる。総合変形量 $110 \mu \mathrm{m}$, 塑性変形量 $6 \mu \mathrm{m} の$ 全デー夕，こ の場合 5 サンプル全てについて各メンバーシップ関数のグ レードを求めた結果を表 1 に示す。メンバーシップ関数毎 にグレードの和（以降，累積グレードと称する）をとる。 この演算を本総合変形量 $(110 \mu \mathrm{m})$ の全塑性変形量に関儿 て行うと図 12 に示すように累積グレードの分布ができる。 各々の累積グレード分布を正規分布とみなし，（5）式を 用いてメンバーシップ関数とした（粽積グレードメンバー シップ関数)。

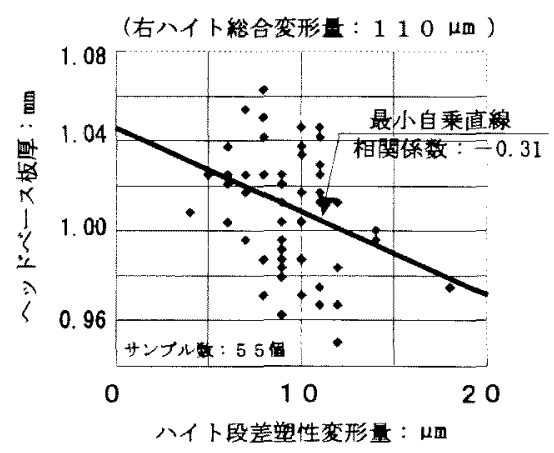

図 10 板厚と塑性変形量の関係 Fig. 10. Relation between head base thickness and plastic deformation. 


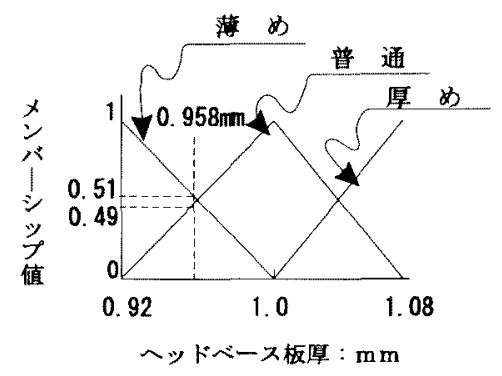

図 11 板厚用メンバーシップ関数

Fig.11. Membership functions for head base thickness.

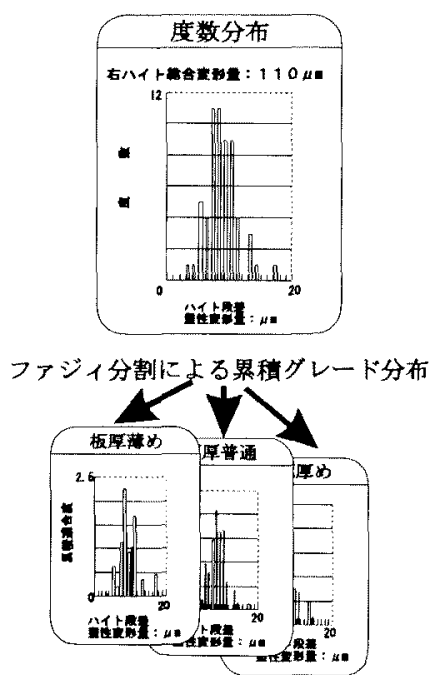

図12 累積グレード分布

Fig.12. Distribution of grade accumulation.

表 1 累積グレード算出方法

Tabel 1. Method of calculation for grade.

\begin{tabular}{|c|c|c|c|c|c|}
\hline \multirow{2}{*}{$\begin{array}{l}\text { 右ハイト } \\
\text { 総合変形量 }\end{array}$} & \multirow{2}{*}{$\begin{array}{l}\text { ハイト段差 } \\
\text { 塑性変形量 }\end{array}$} & \multirow{2}{*}{$\begin{array}{l}\text { ヘッド } \\
\text { ベース板厚 }\end{array}$} & \multicolumn{3}{|c|}{ グレード } \\
\hline & & & 薄い & 普通 & 愿い \\
\hline \multirow{5}{*}{$110 \mu \mathrm{m}$} & \multirow{5}{*}{$6 \mu \mathrm{m}$} & $0.96 \mathrm{~mm}$ & 0.51 & 0.49 & 0.0 \\
\hline & & $1.01 \mathrm{~mm}$ & 0.0 & 0.85 & 0.15 \\
\hline & & $1.01 \mathrm{~mm}$ & 0.0 & 0.90 & 0.10 \\
\hline & & $0.99 \mathrm{~mm}$ & 0.10 & 0.90 & 0.0 \\
\hline & & $1.02 \mathrm{~mm}$ & 0.0 & 0.69 & 0.31 \\
\hline \multicolumn{3}{|c|}{ 累積グレード } & 0.61 & 3.82 & 0.57 \\
\hline
\end{tabular}

この場合，薄めの板厚の塑性変形量の重心は10.1 $\mathrm{m}$ と なり，前節 4 .1において示したルールは以下のようにな る。

$$
\begin{aligned}
& \text { もし 板厚が薄く } \\
& \text { かつ存絶対ハイトを約10.1 } \mu \text { 田変形させる } \\
& \text { ならば右ハイトを110 } \mu \mathrm{m} \text { 変形せよ。 }
\end{aligned}
$$

このようにして，定性的な知見を確率的計算の中に取り
入れた累樍グレードメンバーシップ関数による確率型つァ ジィ推論方式を考案した。

\section{5.磁気へッド調整への適用評価実験結果}

表 2 に実験結果を示す。なお, 調整は 2 回まで許されて いる。算出精度の算定方法は，本アルゴリズムが確率的な 推論方法を取っていることから，正規分布の累積確率を用 いて評価を行っている。

塑性変形量の誤差分布が図 13 のように正規分布してい ると仮定すると, 一定総合変形量時の塑性変形量のばらつ きの平均である平均標準偏差

(1) 式の確率密度関数により塑性変形量誤差の分布老次 式のように表現できる。

$$
f(x)=\frac{1}{\bar{\sigma} \sqrt{2 \pi}} \exp \left(-\frac{1}{2}\left(\frac{x-\bar{d}}{\bar{\sigma}}\right)^{2}\right) \ldots .
$$

この時，図 13 に示すように調整成効率は良否判定仕様笔 团士sにおける (12) 式の累積確率 $F(x)$ により求まる。

$$
F(x)=\int_{-s}^{+s} f(x) d x \quad \cdots \cdots
$$

ここで， $\mathrm{s}$ は良否判定の仕様值である。逆に，平均標準偏 差 $\bar{\sigma}$, 調整成効率 $F(x)$ が判れば近似解法により平均算出睦 差 $\bar{d}$ 求めることができる。

ここで,以前に開発した粗調整装置における従来アルコ リスムとの性能比較を行う。従来アルゴリズムは，ばらつ きの平均值間を区分線形補間し，板厚の影響は考虑してい ない。また，相互干涉は線形連立方程式により考虑してい る。また, 調整 2 回目の際, 調整履歴の考慮はしていない。

表 2 に示すように, 調整 1 回目においては調整量算出精 度は約 4 倍向上している。また，八イト段差の調整仕様値 は，本実験装置の方が粗調整機の1/2であり，高精度な 調整を要求されている。それにもかかわらず，調整成功率 は約 $25 \%$ 向上している。調整 2 回目となったものも成功 率は約 $25 \%$ 向上しており, 調整 2 回目までに成功する率 である総合成功率は調整仕様が笽しくなったにもかかわら ず約 $10 \%$ 向上している。

ばらつきの評価を行う都合上，本評価実験には膨大な ワーク数を必要としたため，板屌の考慮を無視した実験を 別途行うことはできなかつた。そこで，本手法において板 厚を考慮したことによる効果を推定した。例えば，図12 の例の場合，元のばらつきは $3 \sigma=7.49 \mu \mathrm{mであったが,}$ 例えば板厚薄めの果積グレードのばらつきは $3 \sigma=6.57$ 山吆多少小さくなる。本手法において板厚を考慮しない 場合のばらつきより成功率を（13）式を用いて算出すると $86.3 \%$ となる。板厚考虑後のばらつきを用いれば成功 率は $89.6 \%$ となり，3\%程度ではあるが改善されてい ることが予想される。本適用事例においては，図10に示 すように相関係数が-0.31と低すきたため顕著な効果を得 るには到らなかったが累積グレードメンバーシップ関数に よる確率型ファジイ推論方式の原理的な確認を行うことは できた。 


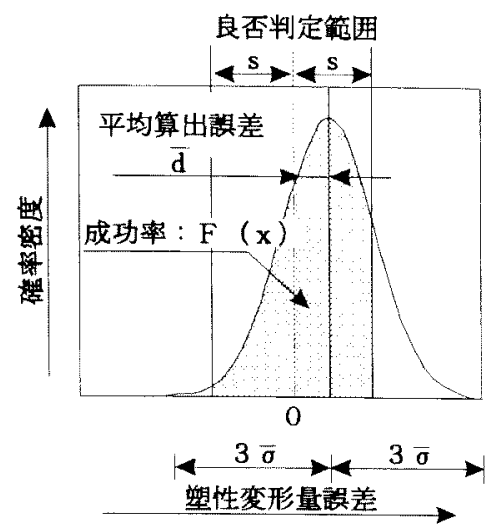

困 13 算出精度評価

Fig.13. Estimation of calculation accuracy.

\section{表 2 実験結果}

Tabel 2. Experimental result.

\begin{tabular}{|c|c|c|c|c|}
\hline & $\begin{array}{l}\text { 本アルゴリ } \\
\text { ズム }\end{array}$ & $\begin{array}{l}\text { 從来アルゴ } \\
\text { リズム }\end{array}$ \\
\hline \multirow{2}{*}{ 調 } & \multirow{3}{*}{$\begin{array}{l}\text { ハイト } \\
\text { 段差調整 }\end{array}$} & 算出精度 & $2.15 \mu \mathrm{m}$ & $8.87 \mu \mathrm{m}$ \\
\hline & & 成功率 & $94.1 \%$ & $69.3 \%$ \\
\hline 1 & & \multicolumn{3}{|c|}{$24.8 \%$ 成功率向上 } \\
\hline 回 & \multirow{3}{*}{$\begin{array}{l}\text { ギャップ } \\
\text { 間距離 } \\
\text { 調整 }\end{array}$} & 算出精度 & $0.004 \mu \mathrm{m}$ & $2.098 \mu \mathrm{m}$ \\
\hline 目 & & 成功率 & $91.5 \%$ & $67.0 \%$ \\
\hline & & & 4. $5 \%$ 成功 & 率向上 \\
\hline \multirow{2}{*}{\multicolumn{2}{|c|}{ 調整 2 回目 }} & 成功率 & $92.3 \%$ & $67.2 \%$ \\
\hline & & & 5. $1 \%$ 成功 & 率向上 \\
\hline \multicolumn{3}{|c|}{ 総合成功率 } & $99.5 \%$ & $89.9 \%$ \\
\hline
\end{tabular}

\section{6.むすび}

本論文では，デー夕のばらつき具合をファジネスとして 捉え，そのばらつきの確率密度関数に基づいてメンバー シップ関数を定義し，確率型フアジィ推諭を提案した。ま たばらつきの原因に付いての定性的な知見をも考慮して メンバーシップ関数を定義し（累積グレードメンバーシッ フ関数），より高精度な推論精度を得る手法を提案した。 以上提案した手法により，従来困難であると考えられてい た高精度制御へのファジィ推論の適用を可能とした。

磁気ヘッド調整により評価実験を行った結果，調整成効 率は99.5\%であり，十分な成功率を得ることができた。ま た，調整精度の低い従来粗調整機と比較しても䄪 $10 \%$ 成功 率は向上しており，その有効性を実証することができた。

最後に，本論文執筆にあたり御指導を頂いた名古屋大学 工学部電子情報学科古橋助教授に梁く感謝の意を表します。

(平成 7 年 9 月 25 日受付，平成 8 年 10 月 30 日再受付)

\section{文献}

1) 石丸伊知郎・平林久明・原美奈子：「弹／塑性変形特 性を用いた精密調整その2(ファジィ理論応用調整 アルゴリズム）」，1991年精密工学会秋季大会学術請 演会講演論文集，pp105-106，（1991）

2 ) 石丸伊知郎・松浦宏育・堀内立夫：「高周波回路自動 調整装置の開発 その2(ファジィ理論応用調整アル ゴリズム）」，1992年精密工学会秋季大会学術講演会 講演論文集，pp463-464，（1992）

3) 高木英行・鈴木規之：「ファジィ推論アーキテクチャ に基づくニューラルネットのV T R テープ走行系調整 工程への適用」, 日本ファジィ学会誌, Vol.3, N04, pp.186-194, (1991)

4) 柴田裕幸：「ファジィ制御を用いたディスプレイモ二 夕管の自動調整」，M S C 技報，N0.3，pp.63-71， (1990)

5 ）長谷川貴史・堀川慎一・古橋 武・内川嘉樹 ·島村 滋・山田稔久. 国武意智・大塚 晋：「転炉吹練ブロ セスのファジィモデリング」, 日本ファジィ学会誌, Vol.5, N0.2, pp.409-419, (1993)

6 ）林勲・野村博義・若見昇：「二ューラルネッ卜駆動 型ファジィ推論による倒立振子の学習制御」，第 5 回 ファジィシステムシンポジウム，pp.55-60, (1989)

7 ）市橋秀友：「 $\mathrm{C}^{\infty}$ 級の階層型ファジィモデル」，第 7 回ファジィシステムシンポジウム, pp.505-508, (1991)

8）片山立・鉺田海平. 梶谷雄治・西田行楎：「自己增 殖型 $\mathrm{C}^{\infty}$ 級ファジィモデルとカオス時系列同定問題への 適用」，第 8 回ファジィシステムシンポジウム， pp.253-256, (1992)

9）堀川慎一・古橋 武・内川嘉樹：「ファジィニューラ ルネットワークの構成と学㿢方法」，日本ファジィ学 会誌, Vol.4, N0.5, pp.906-928,(1992)

10) D.Dubois - H.Prade : rFuzzy Sets - A Convenient Fiction for Modeling Vagueness and Possibility」, Trans. on Fuzzy Systems, Vol.2, No. 7, pp. 16-21, (1994)

11) 原美奈子・平林久明・石丸伊知郎：「弾／塑性変形特 性を用いた精密調整 その1（力七ンサ付き多自由度 高剛性機構）」，1991年精密工学会秋季大会学術講演 会講演論文集, pp103-104,（1991）

12）例えば $\mathrm{E}$ ．クライツィグ著，田島一郎・近藤次郎共 訳：「確率・統計入門」, pp41-43

13）例えば森口繁—・宇田川・一松信：「数学公式 I - 微 分積分・平面曲線一」, p155

14）例えばD V.リンドレ一著，竹内敬・新家健精共訳： 「確率統計入門 1 《ベイズの方法による》確率」， pp58-59 
石丸伊知郎 (正員) 1962年7月6日生まれ。'87年3月大

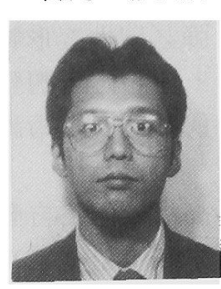

阪大学産業機械工学科卒業。同年（株）日 立製作所入社。同社生産技術研究所におい て，ファジィ，ニューロ等の技術を用いた 熟練官能作業の自動化装置の研究開発に従 事。日本ファジィ学会, 精密工学会会員。

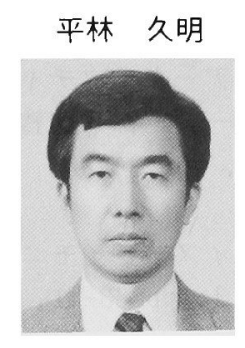

（非会員）1948年9月25日生まれ。'74年3月 早稲田大学工学研究科修士課程機械工学専 攻終了。同年（株）日立製作所入社。以来, ロボットのコンプライアンス制御の研究、 生産自動化用組立, 調整設備の開発に従事。 現在, 同社生産技術研究所プロセス F A 部 主任研究員。工学博士。計測自動制御学会, 日本ロボット学会会員。

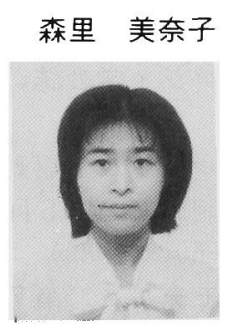

(非会員) 1964年11月16日生まれ。'87年3 月日本女子大学理学部数物科学科卒業。同 年（株）日立製作所入社。同社生産技術研 究所において微細部品の精密調整技術の研 究開発に従事。精密工学会会員。

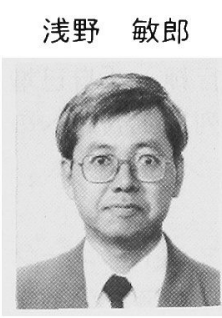

（正員）1948年6月29日生まれ。74年大阪市 立大学大学院工学研究科修士課程電気工学 専攻修了。同年 (株) 日立製作所入社。以 来, 工業用画像認識、電子ディスプレイ検 查、知識応用制御などの研究に従事。現在, 同社生産技術研究所勤務。工学博士。電子 情報通信学会, 情報処理学会会員。

北川 泰治 (非会員) 1967年11月2日生まれ。'92年大阪

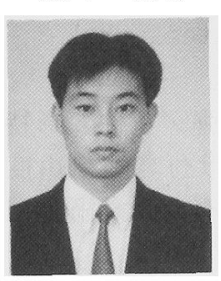
府立大学総合科学部卒業。同年(株) 日立 製作所入社。同社生産技術研究所において, 主に熟練官能作業, 特にディスプレイ管の 画質調整の自動化に従事。 